\title{
Identification of new sources of resistance to powdery mildew in oat
}

\author{
Sylwia Magdalena Okoń • Maria Chrząstek • \\ Krzysztof Kowalczyk • Aneta Koroluk
}

Accepted: 16 December 2013 / Published online: 8 January 2014

(C) The Author(s) 2014. This article is published with open access at Springerlink.com

\begin{abstract}
Powdery mildew caused by Blumeria graminis DC. f. sp. avenae Em. Marchal. is a deleterious foliar disease of common oat which occurs in many parts of the world. Resistance existing in oat cultivars is broken down by new races of this pathogen and because of this fact there is necessity to look for new and effective sources of resistance to powdery mildew in oat. To identify new potential resistance sources to powdery mildew, a total of 67 oat genotypes from five different species Avena sterilis, A. fatua, A. sativa, A. maroccana and A. murphyi and 20 powdery mildew isolates were investigated for disease reactions. Among tested oat accessions the highest level of resistance was associated with A. maroccana genotypes. Genotypes belonging to species of A. murphi and A. sterilis also showed a good level of resistance. Identified genotypes could be used in oat breeding programmes to improve levels of resistance to powdery mildew.
\end{abstract}

Keywords Avena $\cdot$ Host-pathogen tests $\cdot$ Powdery mildew

Powdery mildew caused by Blumeria graminis is a deleterious foliar disease of cereals, including oats (Hsam et al. 1997; Dreiseitl and Wang 2007; Kaur et al. 2008; Silvar et al. 2013). Breeding of resistant

S. M. Okoń $(\bowtie) \cdot$ M. Chrząstek $\cdot$ K. Kowalczyk •

A. Koroluk

Institute of Plant Genetics, Breeding and Biotechnology,

University of Life Science in Lublin, Lublin, Poland

e-mail: sylwia.okon@up.lublin.pl cultivars is one of the most economical and environmentally friendly methods to control this pathogen. Genomic regions responsible for the resistance to powdery mildew in oat are known as Oat Mildew Resistance (OMR) groups (Jones and Jones 1979). Until now, five OMR groups have been described in oat, but there are only a few cultivars that possess powdery mildew resistant genes (Hsam et al. 1997; Kowalczyk et al. 2004; Okoń 2012). Resistance to powdery mildew is decreasing due to the emergence of new strains of this pathogen, thus there is a need to search for novel and effective sources of resistance to powdery mildew in oat (Hsam et al. 1997). The aim of the present study was to identify and characterize new sources of resistance to powdery mildew in wild and cultivated species of oat.

The material for this study consisted of 67 oat genotypes belonging to five different species: Avena sterilis, Avena fatua, Avena sativa (Table 1), Avena maroccana, and Avena murphyi (Table 2). Oat accessions were provided by genebanks: Genebank Gatersleben (Germany), Plant Gene Resources of Canada (Saskatoon, Canada), National Germplasm Resources Laboratory's (Beltsville, USA), and IHAR (Poland).

Host-pathogen tests were carried out according to the method described by Okoń and Kowalczyk (2012). The three most virulent isolates of powdery mildew were used for resistance tests. As a control, cultivars and line with documented OMR groups were used: Bruno (OMR1), Jumbo (OMR2), Mostyn (OMR3), AV1860 (OMR4), and Fuchs susceptible to powdery mildew. Control plant materials were kindly supplied by Sai L.K. Hsam from the Technical University Munich, Germany. 
Table 1 Differential reaction of oat hexaploid species: A. sterilis, $A$. fatua and A. sativa after inoculation with three differential isolates of Blumeria graminis f.sp. avenae

\begin{tabular}{lllc}
\hline Lp & Genotypes & \multicolumn{2}{l}{ Isolates of Blumeria graminis f.sp. avenae } \\
\cline { 2 - 3 } & M 22 & M 31 & M 39 \\
\hline
\end{tabular}

Avena sterilis

$\begin{array}{lll}1 & \text { AVE 531 } & \mathrm{r} \\ 2 & \text { AVE 941 } & \mathrm{s} \\ 3 & \text { AVE 2116 } & \mathrm{r} \\ 4 & \text { PI 287211 } & \mathrm{r} \\ 5 & \text { IHAR E2345 } & \mathrm{r} \\ 6 & \text { IHAR E1228 } & \mathrm{i} \\ 7 & \text { IHAR E 2359 } & \mathrm{i} \\ 8 & \text { AVE 5009 } & \mathrm{r} \\ 9 & \text { AVE 944 } & \mathrm{r} \\ 10 & \text { AVE 849 } & \mathrm{r} \\ 11 & \text { AVE 723 } & \mathrm{s} \\ 12 & \text { AVE 283 } & \mathrm{s} \\ 13 & \text { PI 380125 } & \mathrm{s} \\ 14 & \text { CN 25748 } & \mathrm{s} \\ 15 & \text { AVE 245 } & \mathrm{s} \\ 16 & \text { AVE 446 } & \mathrm{s} \\ 17 & \text { AVE 534 } & \mathrm{s} \\ 18 & \text { AVE 1283 } & \mathrm{s} \\ 19 & \text { AVE 1895 } & \mathrm{s} \\ 20 & \text { AVE 1983 } & \mathrm{s} \\ 21 & \text { AVE 2578 } & \mathrm{s} \\ 22 & \text { AVE 2919 } & \mathrm{s} \\ 23 & \text { AVE 1935 } & \mathrm{s} \\ 24 & \text { AVE 2532 } & \mathrm{s} \\ 25 & \text { AVE 1373 } & \mathrm{s} \\ 26 & \text { Clav 2050 } & \mathrm{s} \\ 27 & \text { Clav 2049 } & \mathrm{s} \\ & & \end{array}$

Avena fatua

28 AVE 270

29 AVE $1322 \quad \mathrm{~s}$

30 AVE $2804 \quad \mathrm{~s}$

31 IHAR E1492 s

32 IHAR E1493 s

33 IHAR E1203 s

34 IHAR E4304 s

35 IHAR E $1667 \mathrm{~s}$

36 IHAR E $2368 \mathrm{~s}$

37 IHAR E $667 \quad \mathrm{~s}$

38 IHAR $51532 \mathrm{~s}$
Table 1 (continued)

\begin{tabular}{llll}
\hline Lp & Genotypes & \multicolumn{3}{l}{ Isolates of Blumeria graminis f.sp. avenae } \\
\cline { 2 - 3 } & M 22 & M 31 & M 39 \\
\hline
\end{tabular}

Avena sativa

39 CIav 3531

$40 \quad$ Clav 4018

41 CIav 4254

$\mathrm{S}$

S

s r

42 CIav 4275

$\mathrm{S}$

43 CIav 6210

44 CIav 7051

45 PI 135731

46 PI 354981

47 PI 502953

$\mathrm{s}$

i

S

r

r

$\mathrm{s}$
$\mathrm{r}$

$s$ susceptible, $i$ intermediate, $r$ resistance

A total of 20 isolates of Blumeria graminis f.sp. avenae were tested for their responses to oat cultivars and lines with documented OMR groups (Table 3). Among tested isolates, three (M22, M31, M39) were chosen to screen different species of genus Avena L. and to search for new potential sources of resistance to powdery mildew. The experiment conducted in the current work showed that the resistance conditioned by OMR1, OMR2 and OMR3 genes was broken down under Polish condition. None of the 20 isolates was avirulent to these genes. Line AV1860 carrying OMR4 gene was the only one resistant to 19 out of 20 isolates. These results suggested that there is a need to identify new effective sources of resistance against powdery mildew in oat.

Many sources of resistance to powdery mildew have been reported in common oat (Jones 1983; Hsam et al. 1997, 1998) as well as in wild relatives of $A$. sativa (Aung et al. 1977; Thomas et al. 1980; Herrmann and Roderick 1996; Hoppe and Kummer 1991; Hayes and Jones 1966). The study of Sebesta et al. (1991) indicated that the line Pc54, which originated from a hybrid between A.sativa cv Pendek and A.sterilis, possessed effective resistance to powdery mildew. Hoppe and Kummer (1991) reported that the line Pc39 was also to some extent resistant to powdery mildew, and could be used as a donor of resistance. Another promising source of resistance to powdery mildew is the line APR 122 derived from a hybrid between $A$. eriantha and A. sativa. The work of Hsam et al. (1997) showed that this line was completely resistant to all isolates of 
Table 2 Differential reaction of oat tetraploid species: A. maroccana and A. murphyi after inoculation with three differential isolates of Blumeria graminis f.sp. avenae

\begin{tabular}{|c|c|c|c|c|}
\hline \multirow[t]{2}{*}{ Lp } & \multirow[t]{2}{*}{ Genotypes } & \multicolumn{3}{|c|}{ Isolates of Blumeria graminis f.sp. avenae } \\
\hline & & M 22 & M 31 & M 39 \\
\hline \multicolumn{5}{|c|}{ Avena maroccana } \\
\hline 1 & AVE 2782 & $\mathrm{r}$ & $\mathrm{r}$ & $\mathrm{r}$ \\
\hline 2 & AVE 2784 & $\mathrm{r}$ & $\mathrm{r}$ & $\mathrm{r}$ \\
\hline 3 & AVE 2785 & $\mathrm{r}$ & $\mathrm{r}$ & $\mathrm{r}$ \\
\hline 4 & AVE 2794 & $\mathrm{r}$ & $\mathrm{r}$ & $\mathrm{r}$ \\
\hline 5 & AVE 2797 & $\mathrm{r}$ & $\mathrm{r}$ & $\mathrm{r}$ \\
\hline 6 & AVE 2799 & $\mathrm{~s}$ & $\mathrm{i}$ & $\mathrm{i}$ \\
\hline 7 & CN 21861 & $\mathrm{r}$ & $\mathrm{r}$ & $\mathrm{r}$ \\
\hline 8 & IHAR 52219 & $\mathrm{r}$ & $\mathrm{r}$ & $\mathrm{r}$ \\
\hline 9 & IHAR 52222 & $\mathrm{i}$ & $\mathrm{i}$ & $\mathrm{i}$ \\
\hline 10 & CN 23040 & $\mathrm{r}$ & $\mathrm{r}$ & $\mathrm{r}$ \\
\hline 11 & CN 22436 & $\mathrm{r}$ & $\mathrm{r}$ & $\mathrm{r}$ \\
\hline 12 & CN 23214 & $\mathrm{r}$ & $\mathrm{r}$ & $\mathrm{r}$ \\
\hline 13 & CN 23220 & $\mathrm{r}$ & $\mathrm{r}$ & $\mathrm{r}$ \\
\hline 14 & CN 23224 & $\mathrm{r}$ & $\mathrm{r}$ & $\mathrm{r}$ \\
\hline 15 & AVE 4709 & $\mathrm{i}$ & $\mathrm{i}$ & $\mathrm{i}$ \\
\hline \multicolumn{5}{|c|}{ Avena murphyi } \\
\hline 16 & AVE 2811 & $\mathrm{~s}$ & $\mathrm{i}$ & $\mathrm{r}$ \\
\hline 17 & CN 21989 & $\mathrm{i}$ & $\mathrm{i}$ & $\mathrm{i}$ \\
\hline 18 & CN 25974 & $\mathrm{r}$ & $\mathrm{i}$ & $\mathrm{i}$ \\
\hline 19 & IHAR/1999/ & $\mathrm{r}$ & $\mathrm{r}$ & $\mathrm{r}$ \\
\hline 20 & CN 23040 & $\mathrm{r}$ & $\mathrm{r}$ & $\mathrm{r}$ \\
\hline
\end{tabular}

$s$ susceptible, $i$ intermediate, $r$ resistance

Blumeria graminis studied at the seedling stage. These results suggested that hexaploid species are a valuable source of genes responsible for resistance. In the present study, three hexaploid species, A. sterilis, A. fatua and A. sativa, were tested. Two genotypes belonging to A. sterilis were resistant to all isolates used in the experiment. The remaining genotypes of $A$. sterilis were resistant to single isolates or showed intermediate responses (Table 1). Accessions of A. fatua tested in this study presented a susceptible or intermediate response to all isolates and had very low levels of resistance to powdery mildew (Table 1 ). Among $A$. sativa accessions, two were resistant to all tested isolates. Although all genotypes studied were resistant to the M39 isolate, after inoculation of M22 and M31 isolates, they showed a susceptible or intermediate response (Table 1). In the current work, genotypes belonging to tetraploid species presented the highest level of resistance. Among Avena species tested, very high levels of resistance were identified in A. maroccana accessions. Twelve genotypes from among 15 were resistant to all isolates of powdery mildew. The remaining A. maroccana genotypes showed an intermediate response (Table 2). Genotypes of $A$. murphyi also had a high level of resistance. The majority of accessions were characterized by resistant or intermediate responses of which two genotypes were resistant to all three isolates included in the experiment (Table 2). Previous studies suggest that the resistance derived from lower ploidy level could be used to improve this trait in common oat. Aung et al. (1977) successfully transferred resistance from the tetraploid species A. barbata into A. sativa. Furthermore, Yu and Herrmann (2006) were also able to effectively transfer the gene conferring resistance to powdery mildew from tetraploid species. However, transfer of a resistance gene between species at the same ploidy level is much easier. The results obtained in our study suggest that selected genotypes could be used as donors of genes encoding

Table 3 Reaction of five differential oat cultivars and lines after inoculation with 20 isolates of Blumeria graminis f.sp. avenae

\begin{tabular}{|c|c|c|c|c|c|c|c|c|c|c|c|c|c|c|c|c|c|c|c|c|c|}
\hline \multirow{3}{*}{$\begin{array}{l}\text { Cultivar/ } \\
\text { line }\end{array}$} & \multicolumn{20}{|c|}{ Isolates of Blumeria graminis f.sp. avenae } & \multirow{3}{*}{$\begin{array}{l}\text { Oat Mildew } \\
\text { Resistance } \\
\text { (OMR) group }\end{array}$} \\
\hline & M & M & M & M & M & M & M & M & M & M & M & M & M & M & M & M & M & M & M & M & \\
\hline & 3 & 4 & 5 & 6 & 8 & 9 & 11 & 12 & 13 & 14 & 18 & 20 & 22 & 31 & 35 & 39 & 41 & 44 & 45 & 46 & \\
\hline Bruno & $\mathrm{s}$ & s & $\mathrm{i}$ & s & s & s & $\mathrm{s}$ & $\mathrm{s}$ & $\mathrm{s}$ & $\mathrm{i}$ & $\mathrm{s}$ & $\mathrm{s}$ & $\mathrm{s}$ & $\mathrm{s}$ & i & $\mathrm{i}$ & $\mathrm{s}$ & $\mathrm{s}$ & $\mathrm{s}$ & $\mathrm{s}$ & 1 \\
\hline Jumbo & $\mathrm{i}$ & $\mathrm{s}$ & $\mathrm{i}$ & $\mathrm{s}$ & $\mathrm{s}$ & $\mathrm{s}$ & $\mathrm{s}$ & $\mathrm{i}$ & $\mathrm{s}$ & $\mathrm{s}$ & $\mathrm{i}$ & $\mathrm{i}$ & $\mathrm{i}$ & $\mathrm{s}$ & $\mathrm{s}$ & $\mathrm{s}$ & $\mathrm{s}$ & $\mathrm{s}$ & $\mathrm{s}$ & $\mathrm{s}$ & 2 \\
\hline Mostyn & $\mathrm{i}$ & $\mathrm{i}$ & $\mathrm{s}$ & $\mathrm{s}$ & $\mathrm{s}$ & $\mathrm{s}$ & $\mathrm{s}$ & $\mathrm{i}$ & $\mathrm{i}$ & $\mathrm{s}$ & $\mathrm{s}$ & $\mathrm{s}$ & $\mathrm{i}$ & $\mathrm{s}$ & $\mathrm{s}$ & $\mathrm{i}$ & $\mathrm{s}$ & $\mathrm{s}$ & $\mathrm{s}$ & $\mathrm{s}$ & 3 \\
\hline Av1860 & $\mathrm{r}$ & $\mathrm{r}$ & $\mathrm{r}$ & $\mathrm{r}$ & $\mathrm{r}$ & $\mathrm{r}$ & $\mathrm{r}$ & $\mathrm{r}$ & $\mathrm{r}$ & $\mathrm{r}$ & $\mathrm{r}$ & $\mathrm{r}$ & $\mathrm{r}$ & $\mathrm{i}$ & $\mathrm{r}$ & $\mathrm{r}$ & $\mathrm{r}$ & $\mathrm{r}$ & $\mathrm{r}$ & $\mathrm{r}$ & 4 \\
\hline Fuchs & $\mathrm{s}$ & $\mathrm{s}$ & $\mathrm{s}$ & $\mathrm{s}$ & s & $\mathrm{s}$ & s & $\mathrm{s}$ & $\mathrm{s}$ & $\mathrm{s}$ & $\mathrm{s}$ & $\mathrm{s}$ & $\mathrm{s}$ & $\mathrm{s}$ & $\mathrm{s}$ & $\mathrm{s}$ & $\mathrm{s}$ & $\mathrm{s}$ & $\mathrm{s}$ & $\mathrm{s}$ & 0 \\
\hline
\end{tabular}

$s$ susceptible, $i$ intermediate, $r$ resistance 
resistance to powdery mildew. Moreover, Hsam et al. (1997, 1998); Kowalczyk et al. (2004) and Okoń (2012) in their study identified some resistant oat cultivars possessed an unknown response pattern compared to control cultivars. These resistant genotypes could be also used as new sources of resistance in oat breeding programs.

The current study has also demonstrated that many genotypes are present in wild relatives of $A$. sativa that could be used as sources of new resistance to powdery mildew. Identified genotypes, especially those resistant to all isolates tested, could be used in oat breeding programs to improve the level of resistance to powdery mildew.

Open Access This article is distributed under the terms of the Creative Commons Attribution License which permits any use, distribution, and reproduction in any medium, provided the original author(s) and the source are credited.

\section{References}

Aung, T., Thomas, H., \& Jones, T. (1977). The transfer of the gene for mildew resistance from Avena barbata (4x) into the cultivated oat $A$. sativa by an induced translocation. Euphytica, 26, 623-632.

Dreiseitl, A., \& Wang, J. (2007). Virulence and diversity of Blumeria graminis f.sp. hordei in East China. European Journal of Plant Pathology, 117(4), 357-368.

Hayes, J. D., \& Jones, I. T. (1966). Variation in the pathogenicity of Erysiphe graminis D.C. f. sp. avenae, and its relation to the development of mildew resistant oat cultivars. Euphytica, 15, $80-86$.

Herrmann, M., \& Roderick, H. W. (1996). Characterisation of new oat germplasm for resistance to powdery mildew. Euphytica, 89, 405-410.

Hoppe, H. D., \& Kummer, M. (1991). New productive hexaploid derivatives after introgression from A. pilosa features. Vortr Pflanzenzuchtg, 20, 56-61.

Hsam, S. L. K., Peters, N., Paderina, E. V., Felsenstein, F., Oppitz, K., \& Zeller, F. J. (1997). Genetic studies of powdery mildew resistance in common oat (Avena sativa L.) I. Cultivars and breeding lines grown in Western Europe and North America. Euphytica, 96, 421-427.

Hsam, S. L. K., Pederina, E., Gorde, S., \& Zeller, F. J. (1998). Genetic studies of powdery mildew resistance in cultivated oat (Avena sativa L.) II. Cultivars and breeding lines grown in Northern and Eastern Europe. Hereditas, 129, 227-230.

Jones, I. T. (1983). Transgressive segregation for enhanced level of adult plant resistance to mildew in the oat cross Mostyn $\times$ Maldwyn. Euphytica, 32, 499-503.

Jones, I. T., \& Jones, E. R. L. (1979). Mildew of oats. UK Cereal Pathogen Virulence Survey 1978. Annual Report, 59-63.

Kaur, N., Street, K., Mackay, M., Yahiaoui, N., \& Kelle, B. (2008). Molecular approaches for characterization and use of natural disease resistance in wheat. European Journal of Plant Pathology, 121, 387-397.

Kowalczyk, K., Hsam, S. L. K., \& Zeller, F. J. (2004). Identification of oat powdery mildew resistance group 2 (OMR2) and Polish common oat (Avena sativa L.) cultivars. Workshop "Resistance of cereals to biotic stresses", Radzików, Poland 28.11-01.12.2004, 122125.

Okoń, S. (2012). Identification of powdery mildew resistance genes in Polish common oat (Avena sativa L.) cultivars using host-pathogen tests. Acta Agrobotanica, 65(3), 63-68.

Okoń, S., \& Kowalczyk, K. (2012). Deriving isolates of powdery mildew in common oat and using them to identify selected genes of resistance. Acta Agrobotanica, 65(2), 155-160.

Sebesta, J., Kummer, M., Roderick, H. W., Hoppe, H. D., Cervenka, J., Swierczewski, A., \& Muller, K. (1991). Breeding oats for resistance to rusts and powdery mildew in central Europe. Ochrana rostlin, 27, 229-238.

Silvar, C., Kopahnke, D., Flath, K., Serfling, A., Perovic, D., Casas, A. M., Igurata, E., \& Ordon, F. (2013). Resistance to powdery mildew in one Spanish barley landrace hardly resembles other previously identified wild barley resistances. European Journal of Plant Pathology, 136(3), 459-468.

Thomas, H., Powell, W., \& Aung, T. (1980). Interferring with regular meiotic behavior in Avena sativa as a method of incorporating the gene for mildew resistance from A. barbata. Euphytica, 29, 635-640.

Yu, J., \& Herrmann, M. (2006). Inheritance and mapping of a powdery mildew resistance gene introgressed from Avena macrostachya in cultivated oat. Theoretical and Applied Genetics, 113, 429-437. 